\title{
A Framework of Subjective Financial Well-Being among University Students in Malaysia
}

\author{
Low, Kah Choon \\ School of Government, UUM COLGIS, \\ Universiti Utara Malaysia, \\ Kedah Darul Aman, Malaysia.
}

Corresponding author: kahchoon@uum.edu.my

\begin{abstract}
Living within one's means is the practice that ensures that a person can survive and able to support their living. However, young working adults in Malaysia struggle to make ends meet for them to cover their basic needs. This problem calls the attention of personal finance management role in improving one's financial well-being. University students are characterised as emerging adults, which their life stage is between adolescents and adults. This emerging stage plays as the transition stage for them before they become a working adult that requires them to manage their own personal finance and not depending on the financial support from their parents. People in a similar financial situation could perceive their financial well-being differently. Due to the specific characteristics of the university students and differences in perceiving their financial well-being, this inspires researcher to investigate the factors (financial literacy and financial behaviour), based on Theory of Planned Behaviour and Happiness Framework, that contribute to financial well-being. Hence, this paper attempted to (1) conceptualise financial well-being in a subjective approach to capture the students' financial wellbeing situation in a more holistic picture and (2) discuss the relationships among the factors contributing to the subjective financial well-being of the university students. It is significant because the concept is defined in varies forms in past studies and the relationships among the factors require further clarifications.
\end{abstract}

Keywords: Perception, Personal Finance, Subjective Financial Well-Being, Financial Literacy, Financial Behaviour, University Students

Received: 17/02/2020 Revised: 18/03/2020 Accepted:13/06/2020 Published: 30/06/2020 


\section{INTRODUCTION}

A report from Agensi Kaunseling dan Pengurusan Kredit- AKPK (2018) points out that Malaysian working adults at the young age of 20-29 struggle to make ends meet for them to be able to cover their basic needs as to achieve their short-term goals rather than achieving the long-term goal for financial resilience. Intensively, the report illustrates that $58 \%$ of the young age from 20-29 would not be able to cover three months' expenses if retrenched and are uncomfortable with their current financial resilience. This report suggested that the financial well-being of young working adults is at a dismal level.

Generally, university students are at the young age group from 18-25, and this group of people is preparing to take up the adult roles and responsibilities in managing their own financial matters. The AKPK report has underlined the concern of poor financial well-being on this group of people when they start to work. Intensively, Van Campenhout (2015) annotated that the young adults' understanding of money matters is indeed emerging from their personal experiences in defining financial well-being. The interpretation for financial well-being derived when they first come across personal finance matters in university (first time start to manage own finance matters), and these experiences are carrying forward until they are starting to work (Rea, Danes, Serido, Borden, \& Shim, 2019).

The interest in exploring the financial well-being of the university students seems to get attention by researchers because at this stage, they have entered the new life experiences, and here is the start for them to begin personal financial management without the supervision of their parents (Xiao et al., 2009; Gutter \& Copur, 2011; Setiyani \& Solichatun, 2019). University students are indeed in the transition stage to become an adult. At this stage, these students are recognised as emerging adults, which they no longer consider as adolescents, and they are in the transition process to adult status.

Financial well-being of emerging adults is more complex compared to adults and adolescents. For emerging adults, the financial well-being can be depending on the student's loan (Montalto, Philips, McDaniel, \& Baker, 2019) and parents in different ways to a different degree (Sorgente \& Lanz, 2019). Moreover, in this life stage, the financial challenges for emerging adults indeed have little differences compared to adolescents (that depends on financial supports from family) and adults (that economic independence from family) and this warrants for the necessity in operationalising and 
validating the concept of financial well-being that adequately fit to emerging adults circumstances (Sorgente \& Lanz, 2019).

Financial well-being has been defined variously, and generally, it can be distinguished in objective and subjective approach (Bruggen et al., 2017; Xiao, Thang, \& Shim, 2009). The objective approach focuses on the total of subject's material resources while subjective approach reflects the self-report evaluation of the subject's financial status (Arber, Fenn, \& Meadows, 2014). The study on students' financial well-being should focus on the behavioural ground (subjective) to understand the behaviour of emerging young adults based on their understanding and the interpretation of satisfactory for their financial status (Bruggen et al., 2017; Rea et al., 2019). However, to date, there are only limited studies that operationalised and validated the concept of subjective financial well-being in a more holistic way (Sorgente \& Lanz, 2019).

According to Hira and Mugenda (1999), subjective well-being is defined as money saved, current financial situation, and financial management skills. However, Bruggen et al. (2017) found that financial well-being should include the present and future situation because the aspects of financial wellbeing are dynamic and individuals' evaluation of subjective financial wellbeing can change over time. Besides, they stated that peers influence the evaluation of subjective financial well-being; thus, the assessment should include peer comparison to determine students' subjective well-being. To date, there are limited studies in Malaysia that includes the assessment of the current and future financial situation, the sufficiency of their material resources to make ends meet, money management, and peer comparison on the financial situation in assessing the students' subjective financial wellbeing. Hence, it raises concern on assessing the level of university students' subjective financial well-being holistically as suggested by past studies.

Past research indicated that better financial literacy leads to better subjective financial well-being (Setiyani \& Solichatun, 2019). In general, financial literacy is defined as financial knowledge from past studies (Bernheim \& Garrett, 1996; Huston, 2010; Lusardi \& Mitchell, 2011; Schmeiser \& Seligman, 2013). However, Warmath and Zimmerman (2019) stated that financial literacy as financial knowledge does not explain the relationship of the knowledge to financial decision making. Indeed, the financial knowledge belongs to a cognitive understanding of the finance matters and not reflects as ability and intentions of a person to apply that knowledge in action (Yong, 
Yew, \& Wee, 2018). This suggests a comprehensive operationalised concept of financial literacy is needed to explain not only financial knowledge but, the ability and intentions of a person to apply that knowledge in action. However, to date, there are only limited studies who has defined the concept of financial literacy in this way; hence, it gives rise for the current study in defining the concept of financial literacy incorporate ability and intentions of a person to apply that knowledge in action. Extensively, this enables the researcher to capture the level of financial literacy of students more holistically compare to past studies.

Many studies posited the link between financial literacy and subjective financial well-being, however, efforts to improve subjective financial wellbeing through financial literacy produce mixed results (Collins \& O' Rourke, 2010). Shim et al. (2009) conducted a study on subjective financial wellbeing among young adults and found that there is no direct relationship between financial literacy and subjective financial well-being. This suggests that the missing piece in explaining how financial literacy contributes to subjective financial well-being. Gutter and Copur (2011) found that financial behaviour is positively linked with subjective financial well-being, while Aggarwal, Gupta, and Singh (2014) found that financial literacy contributes in nature financial behaviour of university students. Based on these studies, it is notable that financial behaviour plays role in explaining the relationship between financial literacy and subjective financial well-being. In order to fill the literature gap in explaining the pathways to attain subjective financial well-being, the current paper suggests that financial literacy contributes in improving the subjective financial well-being of students through better financial behaviour.

\section{LITERATURE REVIEW}

\section{Defining Financial Well-Being}

Financial well-being is defined as "happiness and life satisfaction based on the appraised of an individual's financial situation" (Joo, 2008, pg. 22). The existing literature in defining and measuring of financial well-being can be distinguished into three groups, namely, either subjective or objective approach or the combination of subjective and objective approach (Brüggen, Hogreve, Holmlund, Kabadayi, \& Löfgren, 2017). For objective measures, researchers generally track on the income, wealth to define financial well- 
being of an individual (Urban, Schmeiser, Collins, \& Brown, 2018) or track the financial ratios, benchmarks (Greninger, Hampton, Kitt, \& Achacoso, 1996), or household's ability to manage liquidity (Aggarwal, Gupta, \& Singh, 2014) as determinants to measure the financial well-being. In this respect, past researchers used only objective measures perceived that the great financial status is the ultimate goal for individual happiness (Ferrer-iCarbonell, 2005).

On the other hand, there are groups of researcher that argued the evaluation of the financial situation of a person can incorporate the objective and subjective measures in defining the level of the financial well-being of individuals (Joo \& Grable, 2004; Shim, Baber, Card, Xiao, \& Serido, 2010; Gudmunson \& Danes, 2011). In this regard, the subjective measure reduces the weakness of using the objective measure in helping researchers to examine individuals' perceptions and reactions towards their financial conditions (Norvilitis et al., 2003). For example, Shim et al. (2010) employed both objective (amount of debt) and subjective measure (financial satisfaction and coping with financial strain) in operationalising the financial well-being. The school of thought for the combination of objective and subjective measure suggested that individual's subjective well-being is related to individual's financial condition whereby the rich people are happier and more satisfied with their life compare to the poor ones (Sass, Belbase, Cooperrider, \& RamosMercado, 2015).

The above-mentioned objective indicators or combination of subjective and objective indicators for financial well-being suggests that the financial condition of a person can determine the happiness and life satisfaction. However, the notion of happiness and life satisfaction are indeed subjective in nature, and it depends on how a person perceives his/her well-being status rather than how it is objectively denoted (Bruggen et al., 2017). Moreover, a person's assessment of financial well-being may be different based on these factors such as life stage (Malone, Stewart, Wilson, \& Korsching, 2010), personal characteristics (Joo \& Grable, 2004), comparison with the peers (Ferrer-i-Carbonell, 2005), or other related factors.

Based on the discussion mentioned above on the definition and measurement of financial well-being, current research suggests that subjective approach of financial well-being is more appropriate in capturing human feelings in appraising one's happiness and life satisfaction of his/her financial situation. Indeed, defining financial well-being in subjective approach allows the 
researcher to capture the good or satisfactory condition of a person regarding his/her financial state and the person psychology state of financial interest.

\section{Subjective Financial Well-Being of University Students}

Subjective financial well-being has been studied in various academic fields such as economic, financial planning and consumer decision-making, and yet, there is still no consensus on the definition and measurement of subjective financial well-being. For instance, some defined subjective financial wellbeing as an individual's ability to control daily and monthly finance, and handle uncertainty (Drever, Odders-White, Kalish, Else-Quest, Hoagland, \& Nelms, 2015). On the other hand, some defined it as an individual's overall life satisfaction and measured using satisfaction with life scale (Robb, 2017). In contrast, some defined it as the quality of state on an individual's health in mind and body (Judge, Ilies, \& Dimotakis, 2010).

The different definition and measurement of subjective financial well-being from past research make the operationalised of subjective financial well-being become complicated. In fact, the definition and measurement of subjective financial well-being supposed to measure individual's happiness through cognitive and affective dimensions based on the evaluation of individual's financial situation (Diener \& Oishi, 2000) and not only defined in how they can manage their financial state or physically healthy. Bruggen et al. (2017) stated that the definition of subjective financial well-being should fit on an individual's evaluation of his personal financial well-being. In other words, the assessment of subjective financial well-being is referring to the state of a person feeling towards his/her financial situation. This is regardless of how good of a person quality of state of health in mind and body or the overall satisfaction on his/her life.

Prawitz, Garman, Sorhaindo, Neil, Kim, and Drentea (2006) have defined subjective financial well-being as InCharge Financial Distress/ Financial Well-being (IFDFW), and this scale is widely used as the measurements scale for subjective financial well-being. The IFDFW used financial distress as the core to evaluate the financial well-being level of an individual. In other words, the higher the financial distress of a person, the lower of the financial well-being of the person. Indeed, financial distress is closely linked with financial stress, and it has a narrower scope. Kim, Garman and Sorhaindo (2003) stated that financial distress refers mostly to the ability to meet expenses at a certain point in time. In this regard, Bruggen et al. (2017) 
argued that this definition includes an assessment on current point of time only and has ignored the dynamic of well-being evaluations of individuals that are not static at a certain point on time.

In the context of university students or emerging adults, Sorgente and Lanz (2019) stated that subjective financial well-being has to define in a more holistic picture that includes the different aspects, like cognitive, relational, behavioural satisfaction and temporal. Likewise, Bruggen et al. (2017) also suggested that subjective financial well-being should be defined in four major aspects, such as relational aspect that related to social reference ground, perception of being sustain (current), perception of being sustain (future), anticipated desired living standards and financial freedom. Both of the stated studies have underlain the time dimension of financial well-being (current and future), relational influence on the assessment of financial wellbeing, and financial freedom that consists the evaluation of the sufficiency of material resources.

Based on the literature review, the logic of subjective financial well-being is indeed based on an individual's satisfaction feeling on their financial situation. Intensively, this feeling is indeed come from the peer comparison, individual's belief in his ability to manage the material resources, expectation about their current and future financial situation and their evaluation of the sufficiency of their material resources to make ends meet. In essence, the current paper defined subjective financial well-being as the individual's satisfaction on his/her current financial situation, ability to sustain future financial, ability to manage the material resources, the sufficiency of their material resources to make ends meet and the satisfaction on the financial situation based on peer comparison.

\section{Financial Literacy of University Students}

Financial literacy is essential for university students. At the age when studying in university, students are in a distinct life cycle stage, and this period is known as emerging adulthood (Arnett, 2000). In this stage of life, individual experiences transitional life events with the major life-changing regarding the personal finance matters such as the credit system they have gained access to and money management for life survival. In this regard, the ability of students to deal with financial challenges depend critically on their financial literacy (Ergun, 2017; Rajapakse, 2017). Lack of financial literacy may lead to financial crisis, stress and affecting student's financial well-being 
(Gutter \& Copur, 2011). Speaking on the importance of financial literacy for students, it is important to understand the concept of financial literacy.

Financial literacy is a relatively new term and has been defined by many studies in the past. The most basic definition of financial literacy focuses on financial knowledge that indicates how well an individual can understand and use personal finance-related information (Huston, 2010). The used of knowledge aspect as the only aspect to define financial literacy is indeed underestimate the concept of financial literacy. Knoll and Houts (2012) contended that the address of financial knowledge does not tackle the ability to use this knowledge appropriately to promote financial well-being. For instance, an individual may have adequate financial knowledge, but this does not mean that he or she is able to use the knowledge appropriately.

Likewise, Warmath and Zimmerman (2019) defined financial literacy as financial knowledge that does not explain the relationship of the knowledge towards financial decision making. Indeed, they have suggested a formative combination of financial knowledge, skills and self-efficacy as the operational definition of financial literacy. This formative combination used Bloom's domain of knowledge, defined financial literacy as the combination of the ability to build useful stores of financial knowledge (cognitive), the confidence required to make a financial decision (self-efficacy) and the skill to gather the necessary advice and information needed for a financial decision (psychomotor).

Apart from defining financial literacy as the combination of financial knowledge, skills and self-efficacy, OECD (2017) has defined the financial literacy as "combination of awareness, knowledge, skill, attitude and behaviour to make a sound financial decision and ultimately achieve individual financial well-being". (OECD, 2017, p.13). In this regard, the meaning of financial literacy has been articulated in knowledge, skills, attitude and actual behaviour. Finke and Huston (2014) annotated that financial literacy is indeed modelled as a specific form of human capital that is specific to the knowledge and skills regarding personal finance. The definition of financial literacy should be distinguished from behaviour because financial behaviour falls outside the purview of human capital. Moreover, it includes behaviour in financial literacy may not lead to an understanding of how human capital specific to personal finance is related to financial behaviour and outcome. Hence, financial literacy should include only the assessment of both knowledge and skills related to personal finance rather than includes actual behaviour. 
Despite the differences in definitions, current paper agreed that financial literacy is multi-dimensional and move beyond from only a single measure of financial knowledge (Warmath \& Zimmerman, 2019). Based on Bloom's domain knowledge perspective, Warmath and Zimmerman (2019) stated that to make a sound decision, it includes three domains of knowledge, which are, cognitive, affective and psychomotor (Bloom, Krathwohl, \& Masia, 1984). Explicit knowledge refers to the cognitive domain as recall or recognition of knowledge, self-efficacy refers to the affective domain that describes the changes in attitude, interest and value, and psychomotor domain refers to an emphasis upon the specific development of desirable movement behaviour.

Besides, the current paper investigates financial literacy among university students, and this takes ground from the personal finance area. In this regard, financial literacy can be viewed as a component of human capital because it related to a person's choice wealth along with some chosen level of financial ignorance (Huston, 2010; Lusardi \& Mitchell, 2014). Hence, financial literacy taken in this ground should distinguish itself from the actual financial behaviour. In sum, the current paper defined financial literacy as a multidimensional concept that involved the combination of explicit financial knowledge, skills and self-efficacy in making a sound financial decision. Indeed, this takes ground from the personal finance area because the objective of the current paper is to understand how human capital specifically in the choice of personal finance related to financial behaviour and outcomes.

\section{Relationship between Financial Literacy and Subjective Financial Well- Being of University Students}

Financial literacy means the awareness, skills and knowledge for understanding and analyses financial options to make a sound financial decision (Zulfiqar \& Bilal, 2016). An individual with financial literates can make the sound financial decision so that they can achieve the ultimate goalfinancial well-being. Despite the proliferation of academic studies related to financial literacy, there are a number of studies has tried to link between financial literacy and subjective financial well-being (Shim, Xiao, Barber, \& Lyons, 2009; Taft, Hosein, Mehrizi \& Roshan, 2013; Schmeiser \& Seligman, 2013; Zulfiqar \& Bilal, 2016; Chu, Wang, Xiao \& Zhang, 2017; Setiyana \& Solichatum, 2019).

Financial literacy is not directly contributing to subjective financial wellbeing. Finke and Huston (2014) contend that there is no theoretically direct 
connection between financial literacy and subjective financial well-being. In this regard, they argued that individuals who possess a high level of financial literacy might not necessarily contribute to his/her subjective financial wellbeing because one's with high-level financial literacy may not necessarily used that skills and knowledge in financial decision making and put it in action. Schmeiser and Seligman (2013) found the financial literacy assessment by past research does not necessarily impact subjective financial well-being. They stated that financial literacy simply implies the financial capacity in the broadest sense, and not necessarily guarantee positive financial income.

The study in examines the subjective financial well-being for students has its root on the Theory of Planned Behaviour (TPB) because it predicts and understands the behavioural outcome through the study on an individual's intention to perform given an accepted behaviour (Ajzen, 1991). Based on this ground theory, Shim et al. (2009) have proposed students' financial literacy is related to financial behaviour and financial behaviour is the key to determine subjective financial well-being. In this regard, it explains that the financial literacy as an insight into finance and individual's ability to understand, obtain, and evaluate any information that is relevant in making a financial decision (Prihartono \& Asandimitra, 2018), these channel behavioural outcomes (Schwartz \& Sagie, 2000), and then improve students' subjective financial well-being (Gutter \& Copur, 2011).

\section{Relationship between Financial Literacy and Financial Behaviour of University Students}

Prior studies have documented a relationship between financial literacy and financial behaviour (Falahati, Sabri, \& Paim, 2012; Xiao, Ahn, Serido, \& Shim, 2014; Jamal, Ramlan, Karim, \& Osman, 2015; Setiyani \& Solichatun, 2019). Hilgert, Hogarth, and Beverly (2003) found that financial literacy link with day-to-day financial management activities such as cash-flow management, credit management, saving, and investment. This suggests that financial literacy empower individuals with the ability to make the sound financial decision that ultimately produces accepted financial behaviour. Likewise, Sabri, Cook, and Gudmunson (2012) found that university students that have high financial literacy showed better financial satisfaction. They posited that the increase in financial literacy could result in greater financial behaviour and ultimately improve the student's financial satisfaction.

Xiao et al. (2014) examine the impact of both objective and subjective financial knowledge on financial behaviour regarding risky paying and 
borrowing behaviour among college students in the USA. They found that both objective and subjective financial knowledge play roles in reducing risky borrowing behaviour. Their study suggests that students with better financial literacy help them develop desirable financial behaviour. In the same manner, Jamal et al. (2015) have found that financial literacy contributes to shapes young adult's saving behaviour particularly for the students of higher learning institutions. This result is parallel with the study conducted by Setiyani \& Solichatun (2019) that indicates the positive and significant impact of financial literacy on financial behaviour among university students in Malaysia.

\section{Relationship between Financial Behaviour and Subjective Financial Well- Being of University Students}

Students' financial behaviour contributes to shapes their perception of various life outcome and financial well-being (Curran, Parrott, Ahn, Serido, \& Shim, 2018). The practices related to cash, credit, and saving management (Hilgert et al., 2003) enable students to cope with the life challenges, such as rising costs of living, delays in labour market entry and the payback of student's debt and later contribute to subjective financial well-being. In the transition to adulthood life stage, students develop and getting mature, and they develop the ability to make desired events occurs as a result of their actions. As they are starting to take on adult roles, they encounter more opportunity to make financial choices independently. Hence, the study of students' financial behaviour is important for us to understand their behavioural action and the impact of these actions on their subjective financial well-being.

Problematic financial behaviour by college students may affect their future subjective financial well-being (Worthy, Jonkman, \& Blinn-Pike, 2010). Possible destructive financial behaviour, such as overspending, consuming an emergency fund, incurring debt, or out of saving may lead to significant impact not only on subjective financial well-being but also the life stability of a person (Bruggen et al., 2017). In this regard, Shim et al. (2009) found that the students perceived behavioural control strongly related with subjective financial well-being and this suggested that those who intended to engage in positive financial behaviour are more satisfied with their financial status, less likely to incur debt and better in dealing with financial strains, while the person engages in negative financial behaviour are less satisfied with their financial status and put on an extreme coping pattern when dealing with financial constraints. 
Falahati et al. (2012) found that financial behaviour contributes to predicting the financial satisfaction of university students. The positive financial behaviour may reduce the students involves in risky financial behaviour, and this improves the financial satisfaction. Likewise, Xiao, Tang, and Shim (2009) also found the positive financial behaviour contributes to financial satisfaction and life satisfaction. The study provides evidence to support that encouraging the behaviour domain contributes to increasing satisfaction domain, and not only financial satisfaction but also other satisfaction domains, such as life satisfaction and academic satisfaction. In this sense, they suggest that improvements in the financial domain contribute to improving the student's overall life satisfaction.

\section{Relationship between Financial Behaviour and Subjective Financial Well-Being: Mediating Role of Financial Behaviour}

Following TPB, a person's motivation and ability determined an individual's actual behavioural choices (Ajzen, 1991). In other words, an individual's behaviour achievements depend on the predictor, which is the intention of a person. The intention of a person is associated with the beliefs and beliefs are associated with the awareness of one's behaviour. In this regard, financial behaviour is the behaviour achievement on related financial actions, and financial literacy is the predictor for financial behaviour. Subjective financial well-being is the outcome for financial behaviour. Based on the logic of TPB, financial literacy does not directly form the instant outcome- subjective financial well-being. Indeed, financial literacy forms the beliefs and shape the intention of a person and are associated with the behaviour achievements of a person. The person with financial behaviour contributes to subjective financial well-being.

\section{THEORETICAL FRAMEWORK}

This paper examines the subjective financial well-being of university undergraduate students in describing the relationship between financial literacy and subjective financial well-being through financial behaviour. In other words, the dependent variable in this paper is financial subjective wellbeing and the independent variable is the financial literacy. The financial behaviour is proposed as the mediator that mediates between the independent variable and dependent variable. 


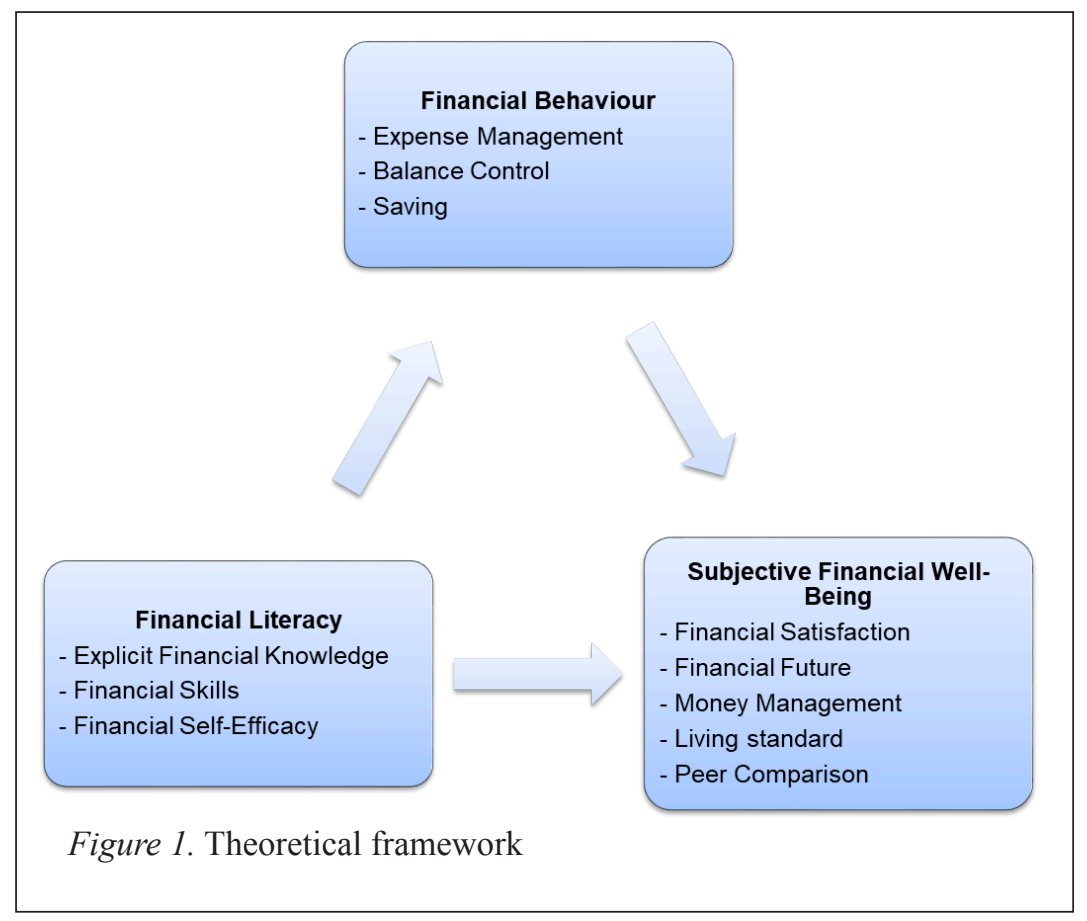

The proposed framework, as illustrated in Figure 1, is developed based on the Theory of Planned Behaviour (TPB) proposed by Ajzen (1985) and Happiness Framework suggested by Lyubomirsky, Sheldon and Schkade (2005). TPB is a theory that explains the behaviour of a person in a specific context (Ajzen, 1991). According to TPB, behaviour achievements depend on intention (motivation), and intention is conceptually determined by attitude toward the behaviour, subjective norms and perceived behavioural control. Arifin (2018) stated that beliefs are associated with the awareness of one's behaviour. Through the process of intensity, someone will do the behaviour in the form of action.

In this paper, financial behaviour is the behaviour achievement on related financial actions, and financial literacy is the predictor for financial behaviour. Financial literacy in this paper is defined in three domains of Bloom's knowledge, and this includes cognitive domain, affective domain and psychomotor domain. This aligned with the predictors suggested using TPB, namely (1) beliefs for the cognitive domain that associated with the awareness of financial knowledge will shape one's behaviour; (2) perceived behavioural control for the affective domain that associated 
with the willingness to accomplish the actions required to achieve specific behaviour; and (3) attitude toward behaviour for the psychomotor domain that associated with the skills that emphasis upon the specific development of desirable movement behaviour.

Financial behaviour is found to contributes in predicting subjective financial well-being in past studies (Curran et al., 2018; Falahati et al., 2012; Gutter \& Copur, 2011; Hilgert et al., 2003; Tang \& Shim, 2009; Worthy et al., 2010). According to the framework by Happiness Framework suggested by Lyubomirsky et al. (2005), one's behaviour is associated with well-being. Based on this assumption, it suggests that individual performing on a domainspecific behaviour will increase his/her happiness related to that domain. In this regard, financial behaviour is domain-specific behaviour, and the domain is the individual's financial happiness.

\section{CONCLUSION}

The present paper contributes to further documenting the subjective financial well-being of university students. Theoretically, it defines the concept of subjective financial well-being in a more holistic approach by incorporating the students' view on the current and future financial situation, the sufficiency of their material resources to make ends meet, money management, and peer comparison on the financial situation in assessing the subjective financial well-being for students. Instead of that, it also identifies the relationships of the factors, such as financial literacy and financial behaviour, contributing to the subjective financial well-being. In practical, this paper contributes to educators, researchers and public policy-makers in designing suitable programs to improve students' subjective financial well-being. This is because subjective financial well-being is positively affecting the quality of life, success, happiness, academic success, physical health, and psychological adjustment (Shim et al., 2009; Gutter \& Copur, 2011).

\section{ACKNOWLEDGEMENT}

This is to acknowledge that this research was funded under the College Research Grant, bearing the SO Code 14549, from the School of Government, UUM COLGIS, Universiti Utara Malaysia. 


\section{REFERENCES}

Aggarwal, N., Gupta, M., \& Singh, S. (2014). Financial literacy among farmers: Empirical evidence from Punjab. Pacific Business Review International, 6(7), 36-42.

Ajzen, I. (1991). The theory of planned behavior. Organizational Behavior and Human Decision Processes, 50(2), 179-211.

AKPK. (2018). Financial behaviour and state of financial well-being of Malaysian working adult. Retrieved from https://www.akpk.org. $\mathrm{my} / \mathrm{sites} /$ default/files/AKPK_Financial\%20Behaviour\%20and\%20 State $\% 20$ of $\% 20$ Finanical $\% 20$ Well-being\%20of\%20Malaysian $\% 20$ Working\%20Adult.pdf

Arifin, A. Z. (2018). Influence factors toward financial satisfaction with financial behavior as intervening variable on Jakarta area workforce. European Research Studies Journal, 21(1), 90-103.

Arnett, J. J. (2000). Emerging adulthood: A theory of development from the late teens through the twenties. The American Psychologist, 55(5), 469-480.

Bloom, B. S., Krathwohl, D. R., \& Masia, B. B. (1984). Bloom taxonomy of educational objectives. United Kingdom: Pearson Education.

Brüggen, E. C., Hogreve, J., Holmlund, M., Kabadayi, S., \& Löfgren, M. (2017). Financial well-being: A conceptualization and research agenda. Journal of Business Research, 79(1), 228-237.

Chu, Z., Wang, Z., Xiao, J. J., \& Zhang, W. (2017). Financial literacy, portfolio choice and financial well-being. Social Indicators Research, 132(2), 799-820.

Curran, M. A., Parrott, E., Ahn, S. Y., Serido, J., \& Shim, S. (2018). Young adults' life outcomes and well-being: Perceived financial socialization from parents, the romantic partner, and young adults' own financial behaviors. Journal of Family and Economic Issues, 39(3), 445-456.

Diener, E., \& Oishi, S. (2000). Money and happiness: Income and subjective well-being across nations. In E. Diener \& E. M. Suh (Eds.), Culture and subjective well-being (p. 185-218). The MIT Press.

Drever, A. I., Odders-White, E., Kalish, C. W., Else-Quest, N. M., Hoagland, E. M., \& Nelms, E. N. (2015). Foundations of financial well-being: Insights into the role of executive function, financial socialization, and experience-based learning in childhood and youth. Journal of Consumer Affairs, 49(1), 13-38.

Ergün, K. (2017). Financial behaviour and financial literacy among university students. Research in Economics and Business: Central and Eastern Europe, 9(2), 77-94. 
Falahati, L., Sabri, M. F., \& Paim, L. H. (2012). Assessment a model of financial satisfaction predictors: Examining the mediate effect of financial behavior and financial strain. World Applied Sciences Journal, 20(2), 190-197.

Ferrer-i-Carbonell, A. (2005). Income and well-being: An empirical analysis of the comparison income effect. Journal of Public Economics, 89(5-6), 997-1019.

Finke, M. S., \& Huston, S. J. (2014). Financial literacy and education. In H. K. Baker and V. Ricciardi (Eds.) Investor Behavior: The Psychology of Financial Planning and Investing (pp. 65-82). Hoboken, NJ: John Wiley \& Sons.

Greninger, S. A., Hampton, V. L., Kitt, K. A., \& Achacoso, J. A. (1996). Ratios and benchmarks for measuring the financial well-being of families and individuals. Financial Services Review, 5(1), 57-70.

Gudmunson, C. G., \& Danes, S. M. (2011). Family financial socialization: Theory and critical review. Journal of Family and Economic Issues, 32(4), 644-667.

Gutter, M., \& Copur, Z. (2011). Financial behaviors and financial well-being of college students: Evidence from a national survey. Journal of Family and Economic Issues, 32(4), 699-714.

Hilgert, M. A., Hogarth, J. M., \& Beverly, S. G. (2003, July). Household financial management: The connection between knowledge and behaviour. [Bulletin]. Federal Reserve Bulletin, 309-322. Retrieved from https://www.federalreserve.gov/pubs/bulletin/2003/0703lead. pdf

Huston, S. J. (2010). Measuring financial literacy. Journal of Consumer Affairs, 44(2), 296-316.

Jamal, A. A. A., Ramlan, W. K., Karim, M. A., \& Osman, Z. (2015). The effects of social influence and financial literacy on savings behavior: A study on students of higher learning institutions in Kota Kinabalu, Sabah. International Journal of Business and Social Science, 6(11), 110-119.

Joo, S. (2008). Personal financial wellness. In J. J. Xiao (Ed.) Handbook of Consumer Finance Research (pp. 21-33). New York, NY: Springer.

Joo, S., \& Grable, J. (2004). An exploratory framework of the determinants of financial satisfaction. Journal of Family and Economic Issues, 25(1), 25-50.

Judge, T. A., Ilies, R., \& Dimotakis, N. (2010). Are health and happiness the product of wisdom? The relationship of general mental ability to educational and occupational attainment, health, and well- 
being. Journal of Applied Psychology, 95(3), 454-468. Doi: 10.1037/ a0019084.

Kim, J., Garman, E. T., \& Sorhaindo, B. (2003). Relationships among credit counselling clients' financial wellbeing, financial behaviors, financial stressor events, and health. Journal of Financial Counseling and Planning, 14(2), 75-87.

Knoll, M. A. Z., \& Houts, C. R. (2012). The financial knowledge scale: An application of item response theory to the assessment of financial literacy. The Journal of Consumer Affairs, 46(3), 381-410. doi: 10.1111/j.1745-6606.2012.01241.x.

Lusardi, A., \& Mitchell, O. S. (2011). Financial literacy around the world: An overview. Journal of Pension Economics \& Finance, 10(4), 497508 .

Lyubomirsky, S., Sheldon, K. M., \& Schkade, D. (2005). Pursuing happiness: The architecture of sustainable change. Review of General Psychology, 9(2), 111-131.

Malone, K., Stewart, S. D., Wilson, J., \& Korsching, P. F. (2010). Perceptions of financial well-being among American women in diverse families. Journal of Family and Economic Issues, 31(1), 63-81.

Montalto, C. P., Phillips, E. L., McDaniel, A., \& Baker, A. R. (2019). College student financial wellness: Student loans and beyond. Journal of Family and Economic Issues, 40(1), 3-21.

Norvilitis, J. M., Szablicki, P. B., \& Wilson, S. D. (2003). Factors influencing levels of credit-card debt in college students. Journal of Applied Social Psychology, 33(5), 935-947.

OECD. (2017). G20/OECD INFE report on adult financial literacy in G20 countries. Retrieved from http://www.oecd.org/daf/fin/financialeducation/G20-OECD-INFE-report-adult-financial-literacy-in-G20countries.pdf

Prawitz, A., Garman, E. T., Sorhaindo, B., O’Neill, B., Kim, J., \& Drentea, P. (2006). InCharge financial distress/financial well-being scale: Development, administration, and score interpretation. Journal of Financial Counseling and Planning, 17(1), 34-50.

Prihartono, M. R. D., \& Asandimitra, N. (2018). Analysis factors influencing financial management behaviour. International Journal of Academic Research in Business and Social Sciences, 8(8), 308-326.

Rajapakse, R. P. C. R. (2017). Financial literacy-A review. International Journal of Research in Finance and Marketing, 7(1), 40-55.

Rea, J. K., Danes, S. M., Serido, J., Borden, L. M., \& Shim, S. (2019). "Being able to support yourself": Young adults' meaning of financial well- 
being through family financial socialization. Journal of Family and Economic Issues, 40(2), 250-268.

Robb, C. A. (2017). College student financial stress: Are the kids alright?. Journal of Family and Economic Issues, 38(4), 514-527.

Sabri, M. F., Cook, C. C., \& Gudmunson, C. G. (2012). Financial well-being of Malaysian college students. Asian Education and Development Studies, 1(2), 153-170.

Sass, S. A., Belbase, A., Cooperrider, T., \& Ramos-Mercado, J. D. (2015). What do subjective assessments of financial well-being reflect? CRR $W P, 3,1-25$.

Schmeiser, M. D., \& Seligman, J. S. (2013). Using the right yardstick: Assessing financial literacy measures by way of financial wellbeing. Journal of Consumer Affairs, 47(2), 243-262.

Schwartz, S. H., \& Sagie, G. (2000). Value consensus and importance: A cross-national study. Journal of Cross-Cultural Psychology, 31(4), 465-497.

Setiyani, R., \& Solichatun, I. (2019). Financial well-being of college students: An empirical study on mediation effect of financial behavior. KnE Social Sciences, 451-474.

Shim, S., Xiao, J. J., Barber, B. L., \& Lyons, A. C. (2009). Pathways to life success: A conceptual model of financial well-being for young adults. Journal of Applied Developmental Psychology, 30(6), 708723.

Shim, S., Barber, B. L., Card, N. A., Xiao, J. J., \& Serido, J. (2010). Financial socialization of first-year college students: The roles of parents, work, and education. Journal of Youth and Adolescence, 39(12), 14571470 .

Sorgente, A., \& Lanz, M. (2019). The multidimensional subjective financial well-being scale for emerging adults: Development and validation studies. International Journal of Behavioral Development, 43(5), 466-478. Doi: 10.1177/0165025419851859.

Taft, M. K., Hosein, Z. Z., Mehrizi, S. M. T., \& Roshan, A. (2013). The relation between financial literacy, financial wellbeing and financial concerns. International Journal of Business and Management, 8(11), 63-75.

Urban, C., Schmeiser, M., Collins, J. M., \& Brown, A. (2018). The effects of high school personal financial education policies on financial behavior. Economics of Education Review, Advanced Online Publication. Doi: 10.1016/j.econedurev.2018.03.006.

Van Campenhout, G. (2015). Revaluing the role of parents as financial socialization agents in youth financial literacy programs. Journal of Consumer Affairs, 49(1), 186-222. 
Warmath, D., \& Zimmerman, D. (2019). Financial literacy as more than knowledge: The development of a formative scale through the lens of Bloom's domains of knowledge. Journal of Consumer Affairs, 53(4), 1602-1629. doi: 10.1111/joca.12286.

Worthy, S. L., Jonkman, J., \& Blinn-Pike, L. (2010). Sensation-seeking, risktaking, and problematic financial behaviors of college students. Journal of Family and Economic Issues, 31(2), 161-170.

Xiao, J. J., Ahn, S. Y., Serido, J., \& Shim, S. (2014). Earlier financial literacy and later financial behaviour of college students. International Journal of Consumer Studies, 38(6), 593-601.

Zulfiqar, M., \& Bilal, M. (2016). Financial wellbeing is the goal of financial literacy. Research Journal of Finance and Accounting, 7(11), 94103. 
